\title{
A new species of Celestus from west-central Panama, with consideration of the status of the genera of the Anguidae: Diploglossinae (Squamata)
}

\author{
Jay M. Savage ${ }^{1}$, Karen R. Lips ${ }^{2,3}$ \& Roberto Ibáñez D. ${ }^{3,4}$ \\ 1 Department of Biology, San Diego State University, San Diego, CA 92182-4614 USA; savy1@cox.net \\ 2 Department of Zoology, Southern Illinois University, Carbondale, IL 62901-6501 USA. Fax: (618) 453-2806; \\ klips@zoology.siu.edu \\ 3 Smithsonian Tropical Research Institute, Apartado 0843-03092 Panamá, Panamá. Fax: (507) 212-8148; \\ ibanezr@si.edu \\ 4 Departamento de Zoología, Universidad de Panamá, República de Panamá.
}

Received 09-X-2006. Corrected 25-X-2007. Accepted 26-XI-2007.

\begin{abstract}
A recently discovered new species of diploglossine lizard is described from west-central Panama. The distinctiveness of the nominal genera Celestus and Diploglossus is confirmed; the new form represents the southernmost record for the genus Celestus. A summary of selected characteristics and general distribution is presented for all recent species of diploglossines, including members of the Antillean genera Saurisia and Wetmorea and the South American genus Ophiodes. A systematic key to mainland members of the genus Celestus is provided. Rev. Biol. Trop. 56 (2): 845-859. Epub 2008 June 30.
\end{abstract}

Key words: Anguids, Squamata, Anguidae, Caribbean, Central America, new species, Panama.

Field parties from Southern Illinois University Carbondale have been studying the amphibians and reptiles of Parque Nacional General de División Omar Torrijos Herrera, north of El Copé, Coclé Province, Panama, since 1998. As part of this effort, collections were made to document the biodiversity of the area's amphibians and reptiles. Among the material obtained was an anguid lizard of the genus Celestus, representing the southernmost known occurrence of the genus on the mainland of the Americas. Comparison of this specimen with all known Celestus indicates that it is a previously undescribed species, which is described herein.

\section{MATERIALS AND METHODS}

Comparative materials are those cited in Savage and Lips (1993). Scale counts and mea- surements also follow the procedures outlined in that publication. Data for the tables are based on material examined for our earlier paper and published descriptions.

Two rather different schemes for denoting the head shields in living diploglossines cause maximum confusion when comparing descriptions and specimens of these lizards. One system, apparently dating from Stejneger (1904), was used by Underwood (1959) with some modification and followed by Schwartz (1964), and has been followed by most subsequent students of West Indian forms. A second, less clearly dating from a single source, has been applied to mainland taxa by such authors as H.M. Smith (1942), Myers (1973), Savage and Lips (1993), and Avila-Pires (1995), among others. This latter system clearly parallels that used for gerrhonotine lizards as formalized by Good (1988) and Campbell and Frost (1993), and applied in slightly modified form 
to northern Mesoamerican diploglossines by Campbell and Camarillo (1994). Even among authors generally using one or the other of these systems, additional inconsistencies have been introduced. The following definitions and descriptions of scale characters apply to all diploglossines, but only those features of lepidosis are treated where there is a difference or ambiguity among various authors (Fig. 1). Abbreviations are those used on the figure.

\section{Upper Head Shields:}

Anterior internasals (2): AI - a pair of shields lying between the nasals and bordering the rostral along its posterior margin; called supranasals by Stejneger (1904) and most students of West Indian forms.

Posterior internasals (2): PI - a pair of shields lying just posterior to the anterior internasals; called frontonasals by Stejneger (1904) and most students of West Indian diploglossines.

Frontonasal: $\mathrm{FN}$ - a single large median shield lying between the frontal and posterior internasals; the azygous prefrontal of Boulenger (1885) or the prefrontal of Stejneger (1904).

Prefrontal (2): PF - shields bordering the frontonasal along its lateral margins on each side and partially separating it from contact with the frontal; frequently fused with the frontonasal to form a single, composite shield, here called the frontonasal; when the two prefrontals are separate, the lizard is described as having two prefrontals and a frontonasal.

Median supraoculars: $\mathrm{SO} / \mathrm{O}$ - a series of moderate sized shields (three to five) lying above the eyes; called supraorbitals by Underwood (1959).

Lateral supraoculars: L - a series of small scales (three to four) lateral to the median supraoculars; called supraciliaries by Cochran (1941) and most workers on West Indian forms.

Interoccipital: $\mathrm{IO}$ - a shield on the midline bordering the parietals and the interparietal; same as the postparietal of many authors or the occipital of Myers (1973), Campbell and
Camarillo (1994), and Werler and Campbell (2004).

Occipital (2): a small scale lateral to the interoccipital on each side.

\section{Lateral Head Surface:}

Postnasal: PN - one or two scales bordering the nasal along its posterior margin; upper called a small supranasal in Diploglossus by Boulenger (1885) and Taylor (1956); called the first loreal by Stejneger (1904) and most West Indian researchers.

Loreal(s) - scales on side of the head between the postnasal(s) and preocular, usually in contact below with supralabials; one to three in number (Table 1):

1st loreal - scale immediately posterior to postnasal(s),

2nd loreal - scale between first loreal and third loreal or the first loreal and preocular,

3rd loreal - scale between second loreal and preocular.

In species having two loreals, the 1st loreal lays in a position that suggests it is homologous to the 2 nd loreal in forms having 3 loreals. In these cases, it seems best to refer to an anterior (= loreal 2) and a posterior loreal (= loreal 3).

Canthal(s) - scales along the side of the head separating the loreals from contact with the upper head shields (Table 1). Canthals may lie in three positions although no diploglossine has three canthals. In some forms there is a canthal (here called i) above the first loreal. When present, this canthal has been called the superior loreal (Taylor 1956) or the upper of two first loreals (Myers 1973). A second canthal (ii) may be present bordering the second loreal above. However, in most taxa canthal ii is fused to the anterior of two loreals or to the $2^{\text {nd }}$ loreal. In one species (Celestus enneagram$m u s$ ) this canthal is fused with the $2^{\text {nd }}$ loreal and the composite scale is often displaced upward away from the supralabials; we follow Campbell and Camarillo (1994) in calling it a displaced second loreal. The third (iii) canthal position is above the last loreal. This 


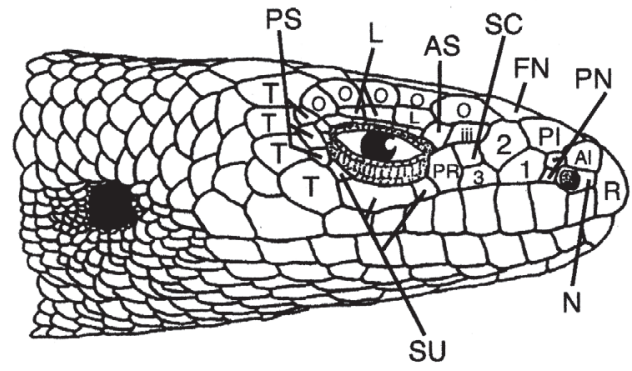

a

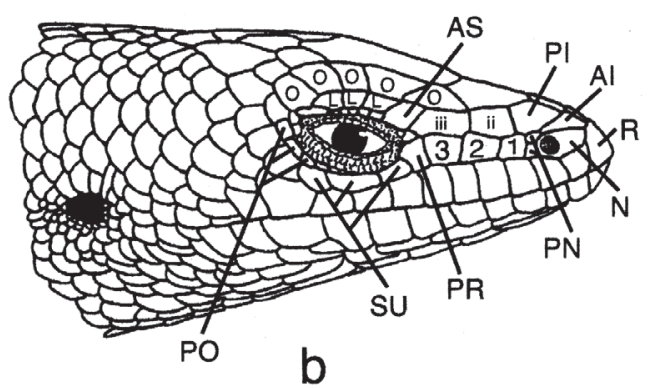

b

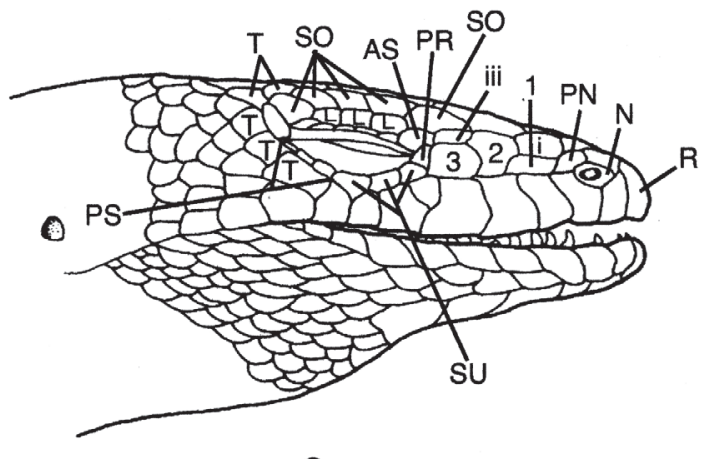

C

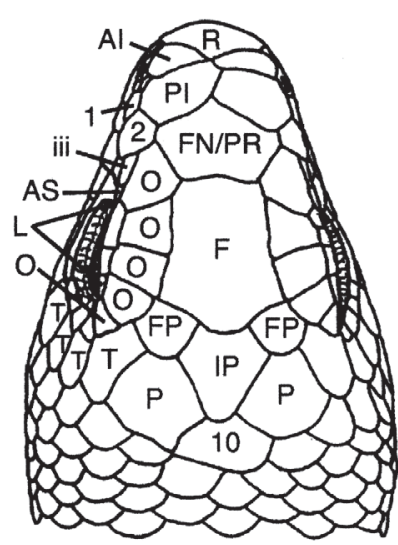

d

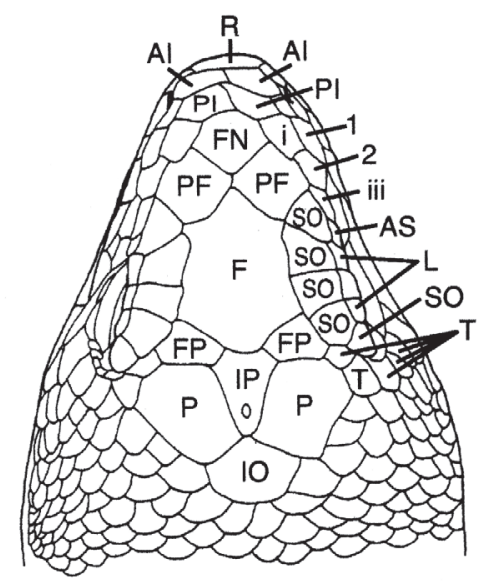

e

Fig. 1. Variation in head scalation in diploglossine lizards: (A) lateral view of head of Celestus rozellae, (B) lateral view of head of C. enneagrammus, (C) lateral view of head of Diploglossus fasciatus, (D) dorsal view of head of C. enneagrammus, (E) dorsal view of head of $D$. fasciatus. $\mathrm{R}=$ rostral, $\mathrm{N}=$ nasal, $\mathrm{F}=$ frontal, $\mathrm{FN}=$ frontonasal, other abbreviations given in Material and Methods. Figures 1A, 1B, 1D modified from Campbell and Camarillo (1994); Figures 1C, 1E from Avila-Pires (1995). 
TABLE 1

Variation in canthal scales among diploglossine species. No specimens of Celestus striatus were examined and no description of these features is available in the literature

I. $\quad 1^{\text {ST }}$ CANTHAL PRESENT (i); 2 $2^{\text {ND }}$ CANTHAL (ii) FUSED WITH $2^{\text {ND }}$ OF 3 LOREALS

Diploglossus fasciatus, D. monotropis

II. NO SEPARATE $1^{\text {ST }}$ CANTHAL (i); $2^{\text {nd }}$ CANTHAL (ii) PRESENT

Celestus adercus, C. atitlanensis (sometimes), C. bivittatus (sometimes), C. cyanochloris, C. hylaius, C. orobius, C. rozellae (usually), Diploglossus bilobatus (usually)

III. NO SEPARATE $1^{\text {ST }}$ OR $2^{\text {ND }}$ CANTHALS (i-ii)

A. $\quad 1^{\text {st }}$ canthal (i) fused with $1^{\text {st }}$ loreal; $2^{\text {nd }}$ canthal (ii) fused with $2^{\text {nd }}$ of 3 loreals Diploglossus millepunctatus

B. $2^{\text {nd }}$ canthal (ii) fused with anterior of 2 loreals

Celestus anelpistus, C. barbouri, C. badius, C. costatus, C. crusculus, C. curtissi, C. darlingtoni, C. duquesneyi, C. enneagrammus, C. fowleri, C. hewardi, C. macrotus, C. marcanoi, C. microblepharis, C. stenurus, C. warreni, Diploglossus bilobatus (some), D. delasagra, D. garridoi, D. lessonae, D. montisilvestris, D. nigropunctatus, D. pleii, Ophiodes intermedius, O. striatus, O. verterbralis, O. yacupoi, Sauresia agasepsoides, S. sepsoides, Wetmorea haetiana

C. $2^{\text {nd }}$ canthal (ii) fused with $2^{\text {nd }}$ of 3 loreals Celestus atitlanensis (sometimes), C. bivittatus (usually), C. legnotus, C. montanus, C. occiduus, C. rozellae (sometimes), C. scansorius, C. ingridae, D. montisserrati

scale is uniformly present in all Celestus and Diploglossus. In some Diploglossus (e.g. D. monotropis) canthals i and iii are present with ii fused to the second loreal. Canthal iii was called the first superciliary by Taylor (1956), the first lateral supraocular (or canthal) by Myers (1973), and the anterior superciliary by Campbell and Camarillo (1994); West Indian researchers usually count this scale as a median supraocular.

Subcanthal: SC - in a few cases (e.g. Celestus macrotus) the posterior loreal is divided by a horizontal suture and the lower portion forms the subcanthal.

Anterior superciliary: AS - the anterior scale in the superciliary series usually bordering the posterior canthal, the upper anterior margin of the orbit, and usually the preocular; it is usually larger than the four to six posterior superciliaries. This is the posterior enlarged superciliary of Campbell and Camarillo (1994).

Preocular: PR - scale bordering the anterior margin of the orbit and contacting the anterior subocular posteriorly below the orbit; sometimes with one or two smaller subpreocular scales above; often called a loreal by West Indian researchers.
Postoculars: PS - scales bordering the orbit posteriorly; called postorbitals by Underwood (1959).

Primary temporals: T - a curved series of moderate sized scales extending from the last supralabial to the frontoparietal lying posterior to the postoculars and supraoculars; the uppermost was called an intercalated scale by Taylor (1956), Myers (1973), and Savage and Lips (1993).

The following abbreviations are used in the measurements section: snout-vent length, $\mathrm{SL}$; tail length, TaL; distance between axilla and groin, A-G; length of arm, A; width at midbody, BW; length of leg, LL; head length, $\mathrm{HL}$; head width, HW; height of head, HH; diameter of orbit, $\mathrm{O}$; diameter of ear opening, EO. Institutional Abbreviations follow Leviton et al. (1985) except for MVUP (Museo de Vertebrados de la Universidad de Panamá) and CH (Círculo Herpetológico de Panamá).

\section{Commentary of the generic status of extant diploglossine genera}

During the $20^{\text {th }}$ century, some instability in the generic allocation of many diploglossine 
taxa resulted from disagreement as to whether or not the extant pentadactyl species comprised one or two genera. Most authors (e.g. Stejneger 1904, Barbour 1910, Burt and Burt 1932, Stuart 1963, Peters and Donoso-Barros 1970, and Meyer and Wilson 1973) recognized Diploglossus Wiegmann, 1834, and Celestus Gray, 1839 as distinct based on the presence or absence of the claw sheath, respectively. Others (e.g. Dunn 1939, Underwood 1959) followed Boulenger's (1885) lead and recognized a single genus, which by priority was Diploglossus.

Strahm and Schwartz (1977) primarily used a new character, the development of the osteoderm canal system, to characterize the two nominal genera. The resulting classification led to a major reassignment of taxa in which species with and without the claw sheath now were placed in both genera. Wilson et al. (1986) subsequently showed ontogenetic variation in canal development and concluded that it was an unreliable diagnostic feature.

Two of the authors of the present paper (Savage and Lips, 1993) reviewed the status of the living genera of anguid lizards placed in the subfamily Diploglossinae and described two new species, Celestus hylaius and C. orobius from Costa Rica. Although they demonstrated the distinctiveness of the genera Celestus and Diploglossus, several subsequent workers (Campbell and Camarillo 1994, Werler and Campbell 2004) have continued to ignore the definitive feature, exposed claws in Celestus versus most of claw concealed in a sheath comprised of five scales in Diploglossus. Savage and Lips (1993) also continued to recognize the Hispaniolan diploglossine tetradactyl genera, Sauresia and Wetmorea, both with claw sheaths, as distinct from Diploglossus. Hedges (1996) synonymized the two nominal tetradactyl genera with Celestus, although they also have claw sheaths unlike other West Indian species all placed in Celestus by Savage and Lips (1993).

A number of taxa belonging to this complex of putative genera have been described or resurrected from synonymy subsequent to our paper. In addition, some molecular studies have addressed the issue of generic relationships so we take this opportunity to review new evidence on generic relations and update the status of valid species and clades (Table 2).

Hedges (1996) briefly referred to immunological distance and DNA sequence data that supported the placement of the four nominal Hispaniolan species referred to "Diploglossus" (anelpistus, carraui $=[$ warreni $]$, marcanoi, and warreni) in Celestus, supporting the assignment by Savage and Lips (1993) to that genus. Similarly, he agreed with Savage and Lips in retaining delasagrai, pleii, and montisserrati in Diploglossus. He also asserted that his data allied the Hispaniolan endemic genera Sauresia and Wetmorea with Celestus. The supposed evidence supporting these conclusions cited by Hedges (Hedges et al. 1992) related only to the immunological distance between the South American diploglossine Ophiodes and Wetmorea. However, evidence for the 1992 conclusions are provided in more detail in Hass et al. (2001), see below.

Macey et al. (1999) using mitochondrial DNA sequences from six species of diploglossines found a sister relationship between Sauresia and Wetmorea and concluded they belonged to a clade containing Diploglossus pleii (Puerto Rico) and Ophiodes striatus (South America) as the sister branch. This result supported the conclusion of Savage and Lips (1993) that Sauresia and Wetmorea are nested within Diploglossus not in Celestus sensu Hedges (1996) and Hass et al. (2001). In addition, Macey et al. (1999) found that $C$. enneagrammus (Mesoamerica) and D. bilobatus (lower Central America) formed a separate lineage. This suggested that Mesoamerican and West Indian Celestus may belong to two different clades, a possibility that needs further investigation. No reference is made in the Macey et al. report to Hedges (1996) and their results were equivocal as only a small subset of the 46 living members of the Diploglossinae and no Antillean Celestus were included in their analysis.

Hass et al. (2001) concluded that there were two major clades of diploglossines in the 
TABLE 2

Character states and geographic distribution of recent diploglossine lizards

\begin{tabular}{|c|c|c|c|c|c|c|c|}
\hline \multirow[t]{2}{*}{$1 \mathrm{FN} / \mathrm{PF}$} & CLAWS EXPOSED & \multicolumn{2}{|l|}{$\begin{array}{c}1 \mathrm{FN}+ \\
2 \mathrm{PF}\end{array}$} & \multirow[t]{2}{*}{$1 \mathrm{FN} / \mathrm{PF}$} & CLAWS SHEATHED & \multicolumn{2}{|l|}{$\begin{array}{c}1 \mathrm{FN}+ \\
2 \mathrm{PF}\end{array}$} \\
\hline & Celestus & & & & Diploglossus & & \\
\hline $\mathrm{CA}$ & adercus,$+ \mathrm{c}$ & $\mathrm{CA}$ & montanus,$+ \mathrm{j}$ & $\mathrm{CA}$ & hilohatus $+\mathrm{u}$ & $\mathrm{CA} / \mathrm{NSA}$ & monotropis \\
\hline $\mathrm{CA}$ & atitlanensis,$+ \mathrm{j}$ & WI & striatus,$- ?$ & & & & $+, \mathrm{s}, \mathrm{c}$ \\
\hline M & ingridae,$+ \mathrm{c}$ & & & $\mathrm{CA}$ & montisilvestris -, s, c & SA & fasciatus u, c \\
\hline $\mathrm{M} / \mathrm{CA}$ & enneagrammus $+, \mathrm{c}, * * *$ & & & SA & lessonae $+, \mathrm{s}, \mathrm{c}$ & MO & $\begin{array}{c}\text { montisserrati } \\
+, \mathrm{s}, \mathrm{c}, *\end{array}$ \\
\hline $\mathrm{CA}$ & bivittatus,$\pm \mathrm{j}$ & & & & & & millepunctatus \\
\hline $\mathrm{CA}$ & cyanochloris,$+ \mathrm{c}$ & & & $\mathrm{C}$ & garrido $+, \mathrm{s}, \mathrm{cf}$ & MA & $+, \mathrm{s}, \mathrm{c}$ \\
\hline $\mathrm{CA}$ & hylaius,$+ \mathrm{j}$ & & & $\mathrm{C}$ & nigropunctatus,+ s, cf & & \\
\hline M & legnotus,$+ \mathrm{c}$ & & & PR & pleii $+, \mathrm{s}, \mathrm{c}$ & & \\
\hline $\mathrm{CA}$ & orobius,$+ \mathrm{j}$ & & & & Sauresia & & \\
\hline $\mathrm{CA}$ & rozellae,$+ \mathrm{j}$ & & & & & & \\
\hline $\mathrm{CA}$ & scansorius,$+ \mathrm{j}$ & & & $\mathrm{H}$ & agasepsoides -, s, c & & \\
\hline $\mathrm{H}$ & anelpistus -, c & & & $\mathrm{H}$ & sepsoides -, s, c & & \\
\hline $\mathrm{H}$ & costatus -, c & & & & Wetmorena & & \\
\hline $\mathrm{H}$ & darlingtoni $-, \mathrm{c},{ }^{* *}$ & & & $\mathrm{H}$ & haetiana -, s, c & & \\
\hline $\mathrm{H}$ & macrotus -, c & & & & NO CLAWS & & \\
\hline $\mathrm{H}$ & marcanoi,$- \mathrm{c}$ & & & & & & \\
\hline $\mathrm{H}$ & stenurus -, c & & & & Ophiodes & & \\
\hline $\mathrm{H}$ & warreni -, c & & & SSA & intermedius -, c & & \\
\hline NI & badius,$+ \mathrm{c}$ & & & SSA & striatus,$- \mathrm{c}$ & & \\
\hline $\mathrm{J}$ & barbouri -, c & & & SSA & vertebralis -, c & & \\
\hline JCI & cusculus -, c & & & SSA & yасupoi -, c & & \\
\hline $\mathrm{J}$ & curtissi -, c & & & & & & \\
\hline $\mathrm{J}$ & duquesneyi -, c & & & & & & \\
\hline $\mathrm{J}$ & fowleri -, c & & & & & & \\
\hline $\mathrm{J}$ & hewardi -, c & & & & & & \\
\hline $\mathrm{J}$ & microblepharis -, c & & & & & & \\
\hline $\mathrm{J}$ & occiduus -, c & & & & & & \\
\hline
\end{tabular}

$\mathrm{C}=$ Cuba, $\mathrm{CA}=$ Central America, $\mathrm{CI}=$ Cayman Islands, $\mathrm{H}=$ Hispaniola, $\mathrm{J}=$ Jamaica, $\mathrm{M}=$ Mexico, MA $=\mathrm{I}$. Malpelo, $\mathrm{MO}$ $=\mathrm{I}$. Montserrat, N = I. Navassa, NSA = Northern South America, SA = South America, SSA = Southern South America, $\mathrm{WI}=$ West Indies. Nasal-rostral contact: $+=$ present, $-=$ absent; postoculars-suboculars: $\mathrm{c}=$ continuous, $\mathrm{j}=$ juxtaposed; postoculars continuous with large supralabial $=\mathrm{cf} ; *=$ frontonasal and prefrontals partially fused; $* *=$ rarely divided into frontonasal and prefrontals; $* * *=$ rarely divided into 2 frontonasals or frontonasal and prefrontals; $\mathrm{u}=$ ungual overlap, $\mathrm{s}=$ subungual overlap. 
West Indies, the three species of Diploglossus (D. delasagra, D. montisserrati, and D. pleii) and Celestus, although they made no reference to the data and conclusions of Macey et al. (1999). This conclusion conformed with the major assignment of species made by Savage and Lips (1993); however, Hass et al. (2001) concluded that Sauresia and Wetmorea were more closely related to Celestus than to Diploglossus, whereas Savage and Lips thought these genera were nested within Diploglossus, although none of the Hedges et al. (1992), Hedges (1996), and Hass et al. (2001) papers contained any DNA sequence data contra Hedges (1996).

Hass et al. (2001) also proposed that Diploglossus may be separated from Celestus (including Sauresia and Wetmorea) by having a nasal-rostral contact as opposed to no contact in Celestus. This conclusion produced nominal genera each containing species with and without the claw sheath. We do not consider the nasal-rostral contact feature an indicator of generic status: there is contact in all mainland Celestus and most Diploglossus (except D. montisserrati); there is no contact in most West Indian Celestus (except C. badius), or in Sauresia or Wetmorea; and contact or lack thereof is intraspecifically variable in some taxa (e.g. C. bivittatus and D. fasciatus).

Because of the small samples and ambiguity of the molecular results we continue to recognize Diploglossus and Celestus on the basis of the presence or absence of the claw sheath, respectively. Although we think that Sauresia and Wetmorea ultimately may be shown to nest within Antillean Diploglossus, it seems best to retain them as distinct taxa until definite confirmation of their relationships are established. Throughout this paper we use the Savage and Lips (1993) concepts of Celestus (no claw sheath) and Diploglossus (claw sheath present) in referring to valid pentadactyl species. As a result all taxa placed in Diploglossus by Campbell and Camarillo (1994) and Werler and Campbell (2004) are here referred to Celestus.

\section{Species account}

Celestus adercus, new species (Fig. 2)

Holotype: Museo de Vertebrados de la Universidad de Panamá, MVUP-1894 (formerly from Círculo Herpetológico de Panamá, $\mathrm{CH}$ 4870), from the abandoned sawmill site on the continental divide, $9.7 \mathrm{~km} \mathrm{NNW}$ of $\mathrm{El}$ Copé, Parque Nacional General de División Omar Torrijos Herrera, La Pintada District, Coclé Province, Panama, ca. $850 \mathrm{~m}\left(8^{\circ} 40^{\prime} 04^{\prime \prime}\right.$ $\mathrm{N}, 80^{\circ} 35^{\prime} 6^{\prime \prime} \mathrm{W}$ ); collected by Tony Ranvestal and Dana Drake in July 2000.

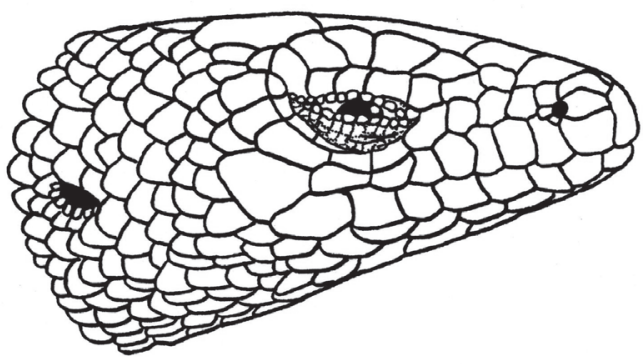

a

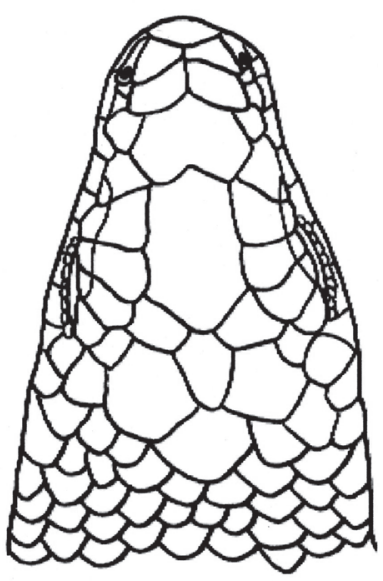

b

Fig. 2. Holotype (MVUP 1894) of Celestus adercus: (A) lateral view of head, (B) dorsal view of head. 
Diagnosis: a moderate-sized Celestus, 146 $\mathrm{mm}$ in total length, differing from C. cyanochloris of Costa Rica and C. enneagrammus, C. ingridae and C. legnotus of northern Mesoamerica in having the postocular series of scales juxtaposed to the suboculars (a single continuous series of postoculars and suboculars in the four listed forms). Among other species having the postoculars juxtaposed, the new species resembles $C$. rozellae of southern Mexico and upper Central America and C. hylaius and C. orobius from Costa Rica. C. adercus differs from $C$. rozellae most obviously in having a median keel on the caudal and subcaudal scales and 79 transverse rows of dorsal scales versus scales on tail without a median keel and 71-76 transverse rows of dorsal scales in $C$. rozellae. Celestus adercus is readily distinguished from C. hylaius of Atlantic versant Costa Rica because the latter has smooth caudal scales and weak keels on the subcaudal scales that are present only on the posterior third of the tail versus caudal scales keeled on all but the base of the tail, and subcaudal scales strongly keeled throughout the length of the tail in the new species. Celestus orobius of upland southern Costa Rica has 66 transverse rows of dorsal scales and one or two loreals (79 transverse rows of dorsal scales and three loreals in $C$. adercus). The new form differs from species of Celestus that occur in the West Indies by having juxtaposed postoculars and suboculars and three loreals rather than having the postoculars and suboculars in a continuous series and only two loreals. The accompanying dichotomous key and Table 3 provide additional features that differentiate the new form from other mainland congeners.

Morphology: rostral much broader than high, distinctly visible from above, in contact with nasals, first supralabial and anterior internasal (supranasal) on both sides; anterior internasals narrower than posterior; frontonasals and prefrontal fused into a single large plate, indented on midline posteriorly, much wider than long, bordered by posterior internasals, frontal, and anterior (ii) canthal and anterior median supraocular; frontal narrow, much longer than wide; frontoparietals small, widely separated by frontal; interparietal much smaller than parietals but separating them, posteriorly touching smaller interoccipital; parietal separated from supraocular by uppermost temporal; nasal single, large nostril posterior to suture between supralabials 1 and 2; 2-2 small, quadrangular postnasals; three loreals, first taller than long; second loreal quadrangular; third loreal slightly smaller; canthal ii quadrangular, not fused with second loreal, larger than third loreal, touching loreals one and two, second internasal, prefrontal and canthal iii; canthal iii large, contacting anterior most lateral and median supraoculars above; five median supraoculars; first median supraocular contacts prefrontal; no large anterior superciliary (possibly fused with canthal iii); four small lateral supraoculars; seven small superciliaries; primary temporals 5-5, lowermost four contacting postoculars; 7-6 scales between postoculars and ear opening; four large postoculars juxtaposed to suboculars; three suboculars; posterior subocular large, rectangular; median subocular elongate, narrow; anterior subocular small; 11-10 supralabials, 8 or 7 to below middle of eye; 9-9 infralabials; mental narrower than rostral; azygous postmental; five pairs of chin shields, first pair in contact with one another and second and third infralabials, others separated by one to five scales; cycloid dorsal scales striate without a median keel; 79 dorsal scales from interoccipital to base of tail; ventral scales smooth; 86 transverse rows of ventral scales from postmental to vent; 31 scales around body; digits laterally compressed, with slightly rounded lamellae; finger lengths $2>5>1,3-4$ longer than others, equal to one another in length; toes relatively long and slender, lengths $4>3>5>2>1 ; 24$ lamellae under toe $4 ; 8$ precloacal scales; caudal scales striate with a strong median keel except on base of tail; subcaudal scales not striate but with a strong median keel.

Coloration in preservative: upper surface of head brown with plate sutures outlined by 


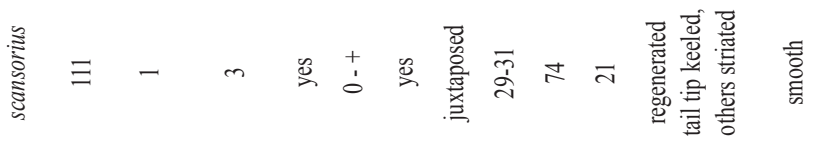

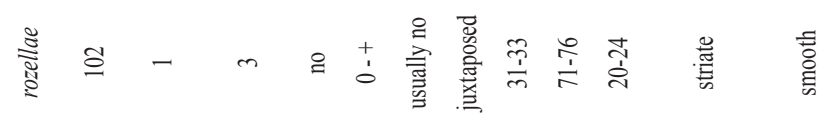

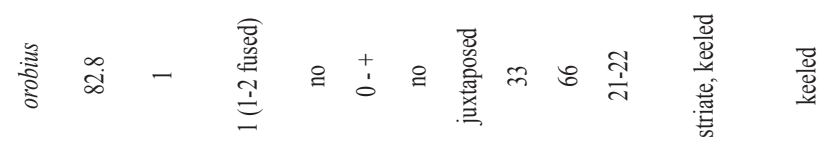

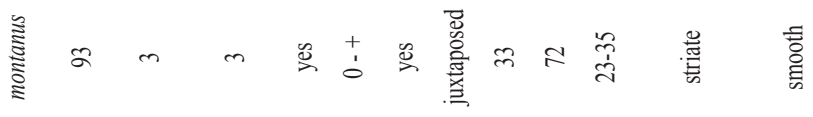

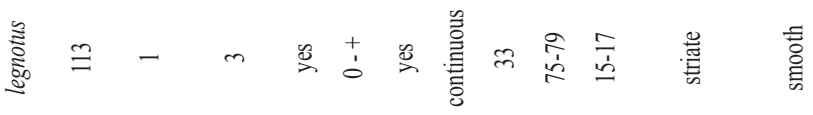

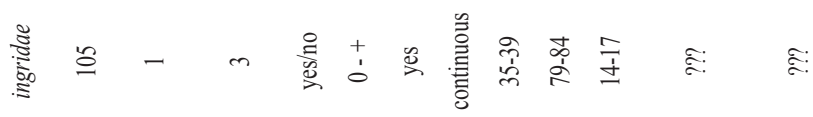

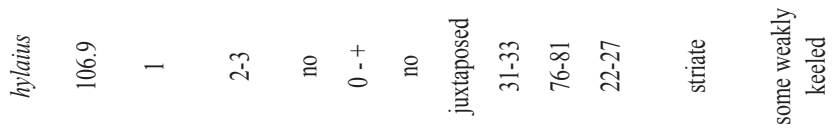

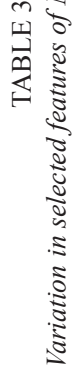

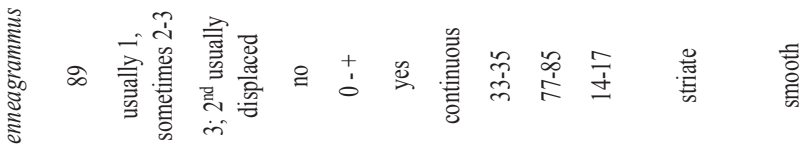

$$
\begin{aligned}
& \text { 竎多 }
\end{aligned}
$$

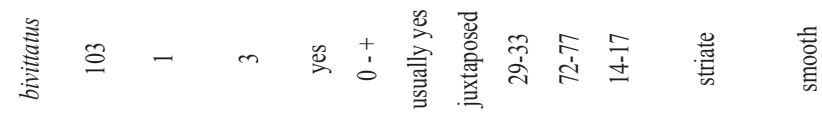

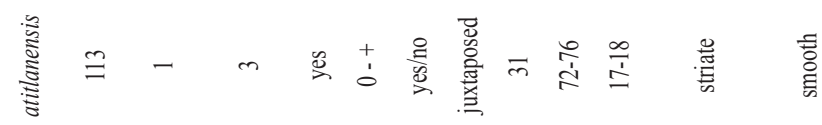

$$
\begin{aligned}
& \text { 竎亲 }
\end{aligned}
$$

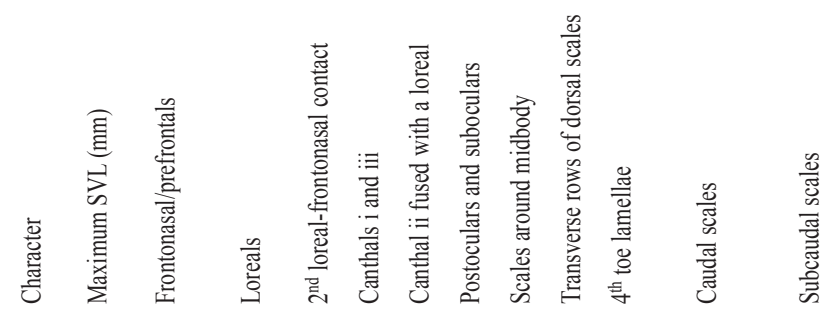


darker brown; side of head brown, supralabials 2-9, bluish-white bordered by brown; most dorsal and lateral scales brown with light dark brown spots; spots irregularly aligned to produce a subtle pattern of obscure light and dark transverse bands; dark spots aligned along lateral rows to form an interrupted dark longitudinal stripe; upper surfaces of limbs and tail nearly uniform dark brown; undersurfaces of throat, venter, and limbs grayish-white with dark pigment concentrated over the canals of the osteoderms to form a series of longitudinal dark stripes (12 on venter); upper surface of base of tail similarly marked but stripes giving way to mottling posteriorly.

Measurements in millimeters (and as percent of SL): SL 74.6; TaL (96\%); A-G 45.3 (61 \%); A 15.6 (21\%); BW 11.0 (14.7\%); LL 20.6 (28 \%); HL 14.3 (19\%); HW 9.0 (12 $\%)$; HH 6.5 (8.7\%); O 3.1 (4.1\%); EO 1.65 $(2.2 \%)$.

Comparisons and possible relationships: the new species belongs to a cluster of species characterized by the putative synapomorphy of juxtaposed postocular and subocular scales. Within this subclade it resembles $C$. hylaius and $C$. orobius of Costa Rica and C. rozellae of Nuclear Central America in having a separate $2^{\text {nd }}$ canthal scale, and shares with $C$. hylaius and C. orobius the presence of keels on at least some of the subcaudal scales. The latter two species are geographically the most proximate in known distribution to $C$. adercus and it seems likely that they are derived from a common ancestor. $C$. adercus and C. orobius are further connected by having keeled caudal scales but differ in the number of transverse dorsal scale rows (79 in the new species versus 66 in C. orobius) and lamellae under the $4^{\text {th }}$ toe ( 24 for $C$. adercus versus 21-22 in C. orobius).

High lamellae counts are suggestive of arboreal or scansorial proclivities in Celestus. C. rozellae (lamellae 20-24) is definitely arboreal (Campbell and Camarillo 1994) and $C$. cyanochloris (lamellae 20-25) appears to be so (Vaughan and Brown 2004). Celestus montanus (lamellae 23-35) is presumed to be arboreal (Campbell and Camarillo 1994) and some evidence (Corn 1981) suggests that C. hylaius (lamellae 22-27) may also be arboreal. Primarily terrestrial forms, C. bivittatus, C. enneagrammus, C. legnotus, and probably C. orobius tend to have lamellae counts in the 14-17 range. However, the recently described $C$. ingridae (lamellae 14-17) showed definite arboreal tendencies (Werler and Campbell 2004) and C. atitlanensis (lamellae 17-18) is arboreal. Serious consideration should be given to the notion that the rarity of many mainland Celestus species in collections may reflect possible arboreal habits and the significance of lamellae number warrants further investigation.

Habitat: the holotype was collected from the thatched roof of a bohio suggesting that this may be an arboreal species.

Distribution: known only from a single Tropical Premontane Rainforest locality near the eastern end of the Serranía de Tabasará in west-central Panama (850 m).

Etymology: the species names is derived from the Greek aderkes meaning unseen, invisible or unexpected in reference to the surprise discovery of this form in Panama as the southernmost mainland known member of the genus.

\section{Recently recognized and enigmatic taxa}

Shortly after the Savage and Lips (1993) opus appeared, Campbell and Camarillo (1994) reviewed the Mesoamerican species of diploglossines, except for the three from Costa Rica. The latter authors referred all previously known species of diploglossines from the region to Diploglossus while describing a new Celestus as D. legnotus from Mexico. They also resurrected $C$. atitlanensis (Guatemala) from the synonymy of $C$. bivittatus (Guatemala to Nicaragua). All of the taxa treated by Campbell and Camarillo (1994) lack the claw sheath and are properly placed in the genus Celestus. 
McCranie and Wilson (1996) described a new form, C. scansorius, from Honduras and continued to regard $C$. atitlanensis as a synonym of C. bivittatus. Werler and Campbell (2004) recently added another species lacking the claw sheath, $C$. ingridae, to the known fauna of Mexico, although referring it to Diploglossus.

Additional taxa added to the West Indies fauna since the Savage and Lips (1993) paper are: C. badius Cope, 1868, elevated to species rank by Powell (1999); D. nigropunctatus Barbour and Shreve, 1937, elevated to species status by Thomas and Hedges (1998); $D$. garridoi Thomas and Hedges, 1998. Celestus carraui Incháutegui, Schwartz, and Henderson, 1985 and C. anelpistus Schwartz, Graham, and Duval, 1979 were reduced to subspecific status by Hallermann and Böhme (2002). Powell and Henderson (2003), however, placed C. carraui as a strict synonym of $C$. warreni and retained C. anelpistus as a valid species.
The enigmatic holotype of $C$. striatus Gray, 1845 was said to be from the West Indies but Schwartz (1964) suggested it might be from Central or South America and Strahm and Schwartz (1977) thought it might be from Central America. The type is $144.5 \mathrm{~mm}$ in standard length, has 41 scale rows around the midbody, two prefrontals and a frontonasal. No Central American Celestus is as large as this specimen, has as many as 41 scale rows around the body and only two (one occasionally) have separate prefrontals and frontonasal. The latter condition is characteristic of $C$. montanus and is variable in C. enneagrammus. No Celestus is known from South America. Thus, this name for the generic type of Celestus, has never been unequivocally associated with any Antillean or Middle American species. Boulenger's (1885, pl. 26, Fig. 1-1A) specimen identified as $C$. striatus is apparently an example of $C$. occiduus (Shaw, 1802).

\section{A KEY TO THE MAINLAND SPECIES OF THE GENUS Celestus}

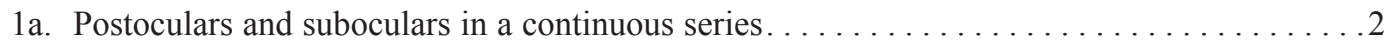

1b. Postoculars and suboculars juxtaposed posterioventral to the orbit $\ldots \ldots \ldots \ldots \ldots$

2a. (1a) Anterior canthal (ii) and loreals usually distinct scales; suture between $1^{\text {st }}$ and $2^{\text {nd }}$ supralabials below anterior margin of naris; 65-73 transverse dorsal scale rows; 20-25 lamellae under

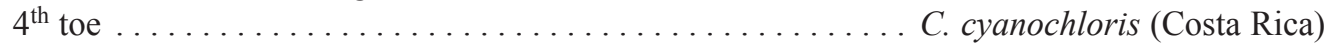

2b. (1a) Anterior canthal (ii) fused with $2^{\text {nd }}$ loreal; suture between $1^{\text {st }}$ and $2^{\text {nd }}$ supralabials below center of naris; 75 or more transverse rows of dorsal scales; 17 or fewer lamellae under $4^{\text {th }}$ toe .

3a. (2b). Posterior margins of upper head shields dark-edged; fused anterior canthal and $2^{\text {nd }}$ loreal usually displaced dorsad so only two loreals border supralabials; a subcanthal usually present; 77-85 transverse rows of dorsal scales; 14-17 lamellae under $4^{\text {th }}$ toe; usually a single frontonasal shield, occasionally two frontonasals or two prefrontals and a frontonasal. . . . . . . . . . $\ldots \ldots \ldots \ldots \ldots \ldots \ldots \ldots \ldots \ldots \ldots \ldots \ldots \ldots \ldots \ldots \ldots \ldots$ enneagrammus (southern Mexico)

3b. (2b). Supracephalic shields uniformly colored or with scant dark edging on a few shields; fused anterior canthal and $2^{\text {nd }}$ loreal not displaced dorsad so three loreals border supralabials; no

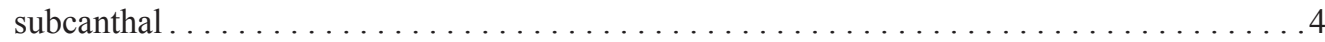

4a. (3b). Scales around midbody 35-39; 79-84 transverse rows of dorsal scales; flank uniform dark brown or with dark bars that are about 8 scale rows wide . . . . . . . . ingridae (Mexico)

4b. (3b). Scales around midbody 33; 75-79 transverse rows of dorsal scales; flanks not uniform with dark bars on flanks about 6 scale rows wide ............. legnotus (Mexico) 
5a. (2b). Frontal shield bordered anteriorly by three plates (two prefrontals and a frontonasal); 72 transverse rows of dorsal scales; 23-35 lamellae under $4^{\text {th }}$ toe ..... C. montanus (Honduras)

5b. (2b). Frontal shield bordered anteriorly by a single large plate (fused prefrontals and frontopa-

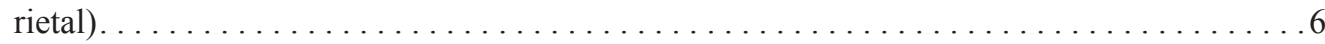

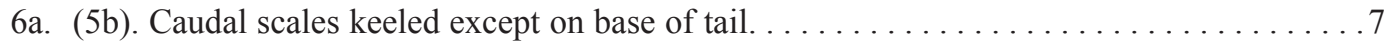

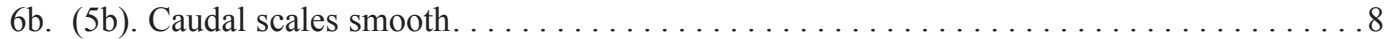

7a. (6a). One or two loreals; 66 transverse rows of dorsal scales; 21-22 lamellae under $4^{\text {th }}$ toe ...

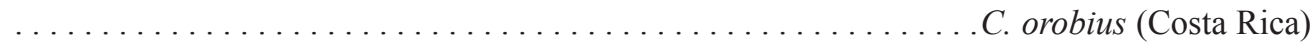

7b. (6a). Three loreals; 79 transverse rows of dorsal scales; 24 lamellae under $4^{\text {th }}$ toe $\ldots \ldots \ldots$ .C. adercus (Panama)

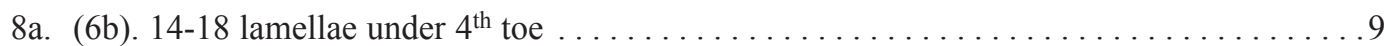

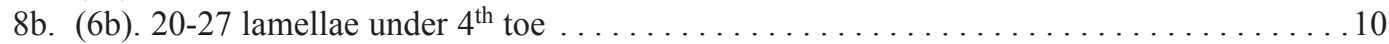

9a. (8a). 14-17 lamellae under $4^{\text {th }}$ toe; standard length to $103 \mathrm{~mm} ; 72-77$ transverse rows of dorsal scales. . . . . . . . . . . . . . . . . . C. bivittatus (Guatemala, Honduras, Nicaragua)

9b. (8a). 17-18 lamellae under $4^{\text {th }}$ toe; standard length to $113 \mathrm{~mm} ; 2$ to 76 transverse rows of dorsal scales . . . . . . . atitlanensis (Guatemala)

10a.(9b). Distinct dark bars on neck and usually on flanks

......................... rozellae (southern Mexico, Guatemala, Belize)

10b.(9b). Neck and flanks without distinct dark bars . . . . . . . . . . . . . . . . 11

11a. (10b). $2^{\text {nd }}$ loreal contacting frontonasal (canthal ii fused with $2^{\text {nd }}$ loreal); 74 transverse rows of dorsal scales; subcaudal scales smooth . . . . . . . . . . . . scansorius (Honduras)

11b.(10b). $2^{\text {nd }}$ loreal not contacting frontonasal (canthal ii not fused with $2^{\text {nd }}$ loreal); $76-81$ transverse rows of dorsal scales; subcaudal scales weakly keeled on posterior one-third of tail . . . .

C. hylaius (Costa Rica).

\section{New record for Celestus orobius}

Celestus orobius was described by Savage and Lips (1993) based on a specimen (LACM 138540) from Costa Rica: San José Province: area near Hortensia, Palma, and Fortuna on the southern slope of the Cordillera de Talamanca (1 500-2 $000 \mathrm{~m}$ ). Todd Castoe, Martin Williams, and Glenn Drawell recently found six to eight individuals referable to this rare species (Fig. 3 ) on the main trail from San Gerardo de Rivas to the summit of Cerro Chirripó Grande, ca. 1.5 $\mathrm{km}$ above the entrance to the Parque Nacional Chirripó, San José Province, Costa Rica (ca. $\left.9^{\circ} 29^{\prime} \mathrm{N}, 83^{\circ} 33^{\prime} \mathrm{W}\right)$, ca. $1800 \mathrm{~m}$. The lizards were on the ground in a small rocky clearing. As the group had no collecting permits no specimens were taken. Close ups of the head indicate that two loreals are present (these are fused in the holotype) and the posterior loreal is separated from the upper head shields by the anterior superciliary. A blue-green area runs along the lateroventral area from the axilla to subcloacal scute. In other regards, the animals in the photos match this species. The new locality is approximately $13 \mathrm{~km}$ west of the type locality in similar habitat and at a similar elevation. 

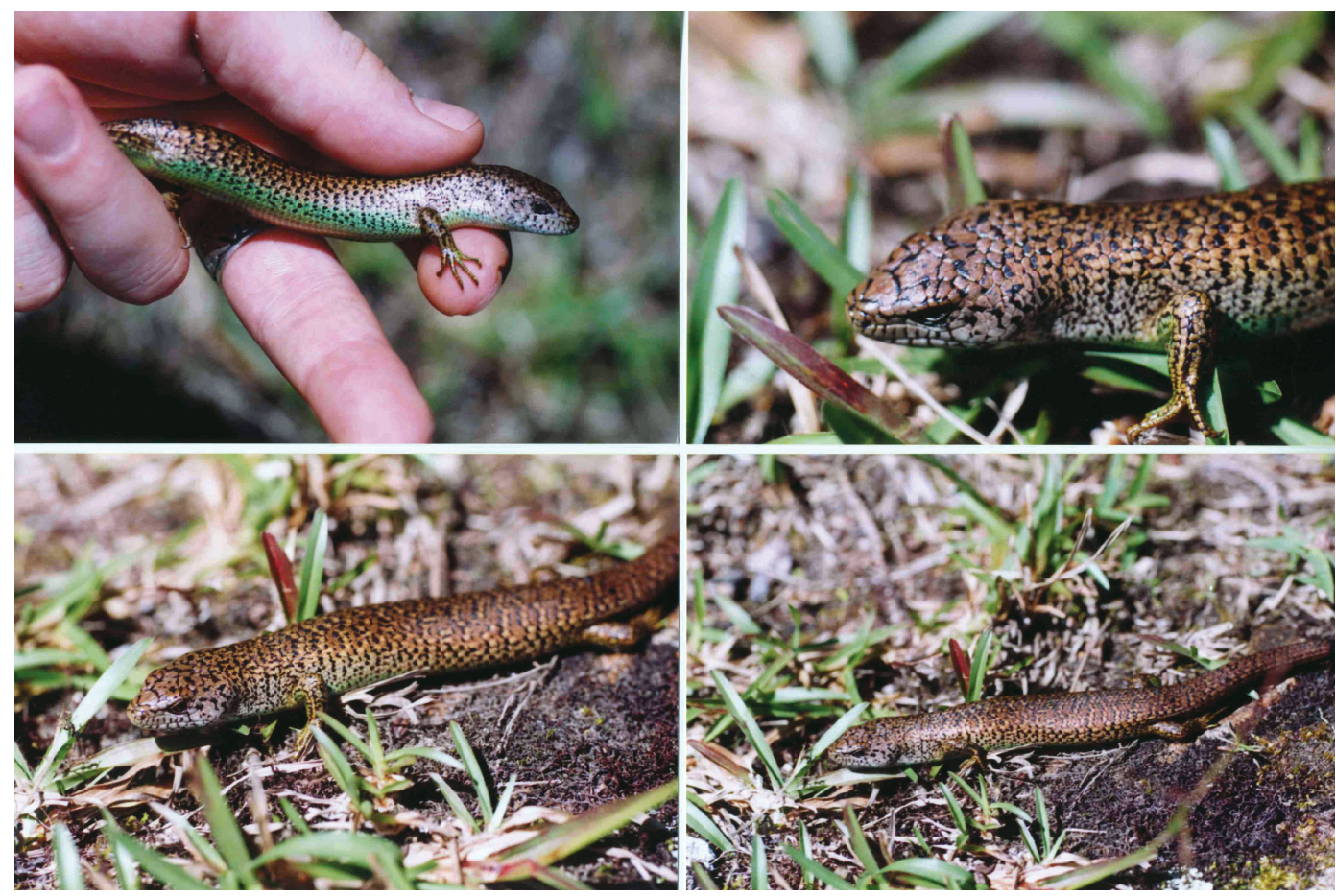

Fig. 3. Celestus orobius from Costa Rica: Provincia de San José: Parque Nacional de Chirripó Grande, 1800 m.

\section{ACKNOWLEDGMENTS}

KRL thanks the personnel of ANAM, and Parque Nacional Omar Torrijos for permission to work in the reserve, and to the Visitors Service Office of STRI for help in obtaining collection permits to study in the area. Funding was provided to KRL by NSF (DEB 0213851, 0234386). K.R. Beaman, R.W. McDiarmid, and J. Rosado made specimens under their care available for study. Cathy Gibbs Thornton prepared Fig. 1, K. Lovich prepared Fig. 2, and T. Castoe provided the photograph of Celestus orobius.

\section{RESUMEN}

Se describe una especie nueva de lagarto diploglossino recientemente descubierta en el centro-oeste de Panamá. Confirmamos la peculiaridad de los géneros nominales Celestus y Diploglossus. La nueva especie representa el registro más al sur del género Celestus. Se presenta un resumen de características selectas y de la distribución general de todas las especies recientes de diploglossinos, incluyendo a los miembros de los géneros antillanos Saurisia y Wetmorea y del género suramericano Ophiodes. Se provee una clave sistemática para los miembros de tierra firme del género Celestus.

Palabras clave: Anguidos, Squamata, Anguidae, Caribe, América Central, especie nueva, Panamá.

\section{REFERENCES}

Avila-Pires, T.C.S. 1995. Lizards of Brazilian Amazonia (Reptilia: Squamata). Zool. Verhandl. Rijksmus. Natur. Hist. Leiden 299: 1-706.

Barbour, T. 1910. Notes on the herpetology of Jamaica. Bull. Mus. Comp. Zool. 52: 273-301.

Barbour, T. \& B. Shreve. 1937. Novitates Cubanae. Bull. Mus. Comp. Zool. 80: 377-387.

Boulenger, G.A. 1885. Catalogue of the Lizards in the British Museum (Natural History). British Museum (Natural History), Taylor and Francis, London, England. 
Burt, C.E. \& M.D. Burt. 1932. South American lizards in the collection of the American Museum of Natural History. Bull. Amer. Mus. Nat. Hist. 61: 1-597.

Campbell, J.A. \& D.R. Frost. 1993. Anguid lizards of the genus Abronia: revisionary notes, descriptions of four new species, a phylogenetic analysis, and key. Bull. Amer. Mus. Nat. Hist. 216: 1-121.

Campbell, J.A. \& J.L. Camarillo. 1994. A new lizard of the genus Diploglossus (Anguidae: Diploglossinae) from Mexico, with a review of the Mexican and northern Central American species. Herpetologica 50: 193-209

Cochran, D.M. 1941. The herpetology of Hispaniola. Bull. U.S. Natl. Mus. 117: 1-398.

Cope, E.D. 1868. An examination of the reptilia and batrachia obtained by the Orton Expedition to Equador and the Upper Amazon, with notes on other species. Proc. Acad. Nat. Sci. Phil. 20: 96-140.

Corn, M.J. 1981. Ecological separation of Anolis lizards in a Costa Rica rain forest. Ph.D. dissertation, University of Florida, Gainesville, Florida, USA.

Dunn, E.R. 1939. The lizards of Malpelo Island, Colombia. Notulae Naturae, Phil. Acad. Natl. Sci. 4: 1-3.

Good, D.A. 1988. Phylogenetic relationships among gerrhonotine lizards. A. Analysis of external morphology. Univ. Cal. Pubs. Zool. 121: 1-139.

Gray, J.E. 1839. A catalogue of the slender-tongued saurians, with descriptions of many new genera and species. Ann. Mag. Nat. Hist. ser 2, 1: 288-293.

Gray, J.E. 1845. Catalogue of the Specimens of Lizards in the Collection of the British Museum, British Museum, London, England.

Hallermann, J. \& W. Bohme. 2000. On the taxonomic status of the giant galliwasps from Hispaniola (Anguidae: Celestus warreni group). Biota 2: 70-71.

Hass, C.A., L.R. Maxson \& S.B. Hedges. 2001. Relationships and divergence times of West Indian amphibians and reptiles: insights from albumin immunology, p. 157-174. In C.A. Woods \& F.E. Sergile (eds.). Biogeography of the West Indies: patterns and perspectives. CRC, Boca Raton, Florida, USA.

Hedges, S.B., C.A. Hass \& L.R. Maxon. 1992. Caribbean biogeography: molecular evidence for dispersal in West Indian terrestrial vertebrates. Proc. Natl. Acad Sci. USA 89: 1909-1913.
Hedges, B.S. 1996. The origin of West Indian amphibians and reptiles, p. 95-128. In R. Powell \& R.W. Henderson (eds.). Contributions to West Indian herpetology: A tribute to Albert Schwartz. Soc. Stud. Amphib. Rept. Ithaca, New York, USA.

Incháutegui, S.J., A. Schwartz \& R.W. Henderson. 1985. Hispaniolan giant Diploglossus (Sauria, Anguidae): description of a new species and notes on the ecology of D. warreni. Amphibia-Reptilia 6: 195-201.

Leviton, A.E., R.H. Gibbs Jr., E. Heal \& C.E. Dawson. 1985. Standards in herpetology and ichthyology. Part I. Standard symbolic codes for institutional resource collections in herpetology and ichthyology. Copeia 1985: 802-832.

Macey, J.R., J.A.I. Schultze, A. Larson, B.S. Tuniyev, N. Orlov \& T.J. Papenfuss. 1999. Molecular phylogenetics, tRNA evolution, and historical biogeography in anguid lizards and related taxonomic families. Molec. Phylog. Evol. 12: 250-272.

McCranie, J.R. \& L.D. Wilson. 1996. A new arboreal lizard of the genus Celestus (Squamata: Anguidae) from northern Honduras. Rev. Biol. Trop. 44: 259-264.

Meyer, J.R. \& L.D. Wilson. 1973. A distributional checklist of the turtles, crocodilians, and lizards of Honduras. Contrib. Sci. Nat. Hist. Mus. L.A. Co. 244: 1-39.

Myers, C.W. 1973. Anguid lizards of the genus Diploglossus in Panama, with the description of a new species. Amer. Mus. Nat. Hist. Novit. 2523: 1-20.

Peters, J.A. \& R. Donoso-Barros. 1970. Catalogue of the Neotropical Squamata: Part II. lizards and amphisbaenians. Bull. U.S. Nat. Mus. 297: 1-193.

Powell, R. 1999. Herpetology of Navassa Island, West Indies. Carib. J. Sci. 35(1-2): 1-13.

Powell, R. \& R.M. Henderson. 2003. The taxonomic and conservation status of giant Hispaniolan Celestus (Anguidae). Carib. J. Sci. 39: 237-240.

Savage, J.M. \& K.R. Lips. 1993. A review of the status and biogeography of the lizard genera Celestus and Diploglossus (Squamata: Anguidae), with description of two new species from Costa Rica. Rev. Biol. Trop. 41: 817-842.

Schwartz, A. 1964. Diploglossus costatus Cope (Sauria, Anguidae) and its relatives in Hispaniola. Sci. Pubs. Read. Publ. Mus. Art Gall. 13: 1-57. 
Schwartz, A., E.D. Graham, Jr. \& J.J. Duval. 1979. A new species of Diploglossus (Sauria: Anguidae) from Hispaniola. Proc. Biol. Soc. Wash. 92: 1-9.

Shaw, G. 1802. General Zoology or Systematic Natural History. Thomas Davison, London, England.

Smith, H.M. 1942. Mexican herpetology miscellany. Proc. U.S. Natl. Mus. 92: 349-395.

Stejneger, L.H. 1904. The herpetology of Puerto Rico. Ann. Rept. U.S. Nat. Hist. Mus. 1904, pp. 547-724.

Strahm, M.H. \& A. Schwartz. 1977. Osteoderms in the anguid lizard subfamily Diploglossinae and their taxonomic importance. Biotropica 9: 58-72.

Stuart, L.C. 1963. A checklist of the herpetofauna of Guatemala. Misc. Publ. Mus. Zool. Univ. Michigan 122: $1-150$.

Taylor, E.H. 1956. A review of the lizards of Costa Rica. Univ. Kansas Sci. Bull. 38: 3-322.
Thomas, R. \& S.B. Hedges. 1998. A new anguid lizard (Diploglossus) from Cuba. Copeia 1998: 97-103.

Underwood, G. 1959. A new Jamaican galliwasp (Sauria, Anguidae). Mus. Comp. Zool. Breviora 102: 1-13.

Vaughan, A. \& J.L. Brown. 2004. Celestus cyanochloris (NCN). Arboreal behavior. Herp. Rev. 35: 387.

Werler, J.E. \& J.A. Campbell. 2004. New lizard of the genus Diploglossus (Anguidae: Diploglossinae) from the Tuxtlan faunal region Veracruz, Mexico. SW Nat. 49: 327-333.

Wiegmann, A.F.A. 1834. Herpetologia Mexicana seu DescriptioAmphibiorum Novae Hispaniae. Pars Prima Saurorum Species, Lüderitz, Berlin, Deutchland.

Wilson, L.D., L. Porras \& J.R. McCranie. 1986. Distributional and taxonomic comments on some members of the Honduran herpetofauna. Contribs. Biol. Geol. Milwaukee Publ. Mus. 66: 1-18. 